\title{
PENGARUH PERENCANAAN KARIR ORGANISATIONAL DAN INDIVIDUAL TERHADAP KEPUASAN KERJA DAN KENERJA KARYAWAN
}

\author{
Desak Made Indah Paramitha Sari1 \\ I Made Wardana2 \\ 1Fakultas Ekonomi dan Bisnis Universitas Udayana (Unud), Bali, Indonesia \\ E-mail : indahchocochip@yahoo.com
}

\begin{abstract}
The Effect of Organizational and Individual Career Planning on Job Satisfaction and Employee Performance. The aims of this research is to determine the influence of organizational and individual career planning to job satisfaction and employee performance PDAM Denpasar. The sample in this study was 135 people from PDAM Employees Denpasar that taken by proportional stratified random sampling method. The data analysis technique used is structural equation modeling (SEM) which computerized by using the program AMOS version 6. The results showed that organizational and individual career planning has positive and significant impact on employee job satisfaction PDAM Denpasar. Organizational career planning and individual influence on employee performance PDAM Denpasar and job satisfaction affects employee performance PDAM Denpasar. The implications of this research ;s to be repaired organizational and individual career planning and improvement of job satisfaction and employee performance PDAM Denpasar.
\end{abstract}

Keywords: Career planning organizational; individual career planning; job satisfaction; employee performance.

\begin{abstract}
Abstrak: Pengaruh Perencanaan Karir Organisational dan Individual Terhadap Kepuasan Kerja dan Kenerja Karyawan. Penelitian ini bertujuan untuk mengetahui pengaruh perencanaan karir organisasional dan individual terhadap kepuasan kerja dan kinerja karyawan PDAM Kota Denpasar. Sampel dalam penelitian ini adalah 135 orang. Karyawan PDAM Kota Denpasar yang diambil dengan metode proportional stratified random sampling. Teknik analisis data yang digunakan adalah Structural Equation Modelling (SEM) yang dikomputasi dengan menggunakan Program AMOS versis 6. Hasil penelitian menunjukkan bahwa perencanaan karir organisasional dan individual berpengaruh positif dan signifikan terhadap kepuasan kerja karyawan PDAM Kota Denpasar. Perencanaan karir organisasional dan individual berpengaruh terhadap kinerja karyawan PDAM Kota Denpasar dan kepuasan kerja berpengaruh terradap kinerja karyawan PDAM Kota Denpasar. Implikasi dari penelitian ini adalah agar dilakukan perbaikan perencanaan karir organisasional dan individual serta perbaikan terhadap kepuasan kerja dan kinerja karyawan PDAM Kota Denpasar.
\end{abstract}

Kata kunci: Perencanaan karir organisasional; perencanaan karir individual; kepuasan kerja; kinerja karyawan 


\section{PENDAHULUAN}

Manusia dalam kemajuan suatu perusahaan sangat penting, maka sudah sepantasnya para pimpinan memperhatikan hal-hal yang dapat memotivasi para karyawan, untuk mencapai apa yang mereka inginkan. Tujuan karyawan dalam bekerja antara lain, untuk memperoleh penghargaan atau aktualisasi did. Tujuan tidak tercapai akan dapat berpengaruh pada kepuasan kerja karyawan yang nantinya akan berdampak pada kinerja karyawan dan kinerja organisasi secara keseluruhan. Kepuasan kerja dan kinerja karyawan dalam suatu organisasi sangat penting, karena diyakini kepuasan kerja yang tinggi dari karyawan akan mendorong meningkatnya kinerja individu, yang nantinya akan mempengaruhi pula kinerja organisasi secara keseluruhan.

Perusahaan Daerah Air Minum (PDAM) Kota Denpasar adalah salah satu perusahaan daerah yang dimiliki oleh pemerintah Kota Denpasar. Banyak sekali tantangan yang dihadapi oleh PDAM Kota Denpasar saat ini seperti debit air yang semakin menipis, oleh karena itu agar dapat melakukan pengelolaan perusahaan dengan baik, maka PDAM Kota Denpasar hams didukung oleh karyawan yang berkompeten dan memiliki semangat kerja tinggi. Semangat kerja yang tinggi akan dapat mempengaruhi kinerja dari karyawan, maka pekerjaan yang diberikan kepadanya akan dapat diselesaikan dengan waktu yang lebih singkat atau bahkan mungkin lebih cepat sehingga kepuasan kerja karyawan sudah tercapai, yang nantinya akan menyebabkan kinerja yang tinggi pula dari karyawan tersebut.

Penilaian kinerja karyawan PDAM Kota Denpasar dilakukan oleh atasan langsung karyawan yang bersangkutan. Selain penilaian kinerja oleh atasan langsung, kinerja karyawan juga dapat diukur melalui jumlah keluhan atau komplain dari pelanggan, atas pelayanan yang diberikan oleh PDAM Kota Denpasar, Jumlah keluhan dari pelanggan yang tersaji pada Tabel 1

Tabel 1 dapat dilihat bahwa total keluhan pelanggan selama tahun 2008 adalah sebesar 6.340, sedangkan total keluhan pelanggan selama tahun 2009 yaitu sebesar 6.732. Dari dua tahun keluhan pelanggan tersebut, dapat dilihat bahwa telah terjadi kenaikan total keluhan, yaitu sebesar 392. Begitu pula dengan total pelanggan selama tahun 2008 adalah sebesar 65.786, sedangkan tahun 2009 adalah sebesar 66.583. Dari dua tahun ini juga dapat dilihat kenaikan total pelanggan sebesar 797. Dan adanya kenaikan persentase keluhan pelanggan tahun 2008 sebesar 9,64 persen dan tahun 2009 sebesar 10,llpersen. Kenaikan total keluhan pelanggan yang cukup besar, kenaikan total pelanggan dan kenaikan persentase keluhan pelanggan mengindikasikan adanya penurunan kinerja karyawan. Penurunan kinerja karyawan apabila tidak ditangani dengan baik akan dapat menyebabkan terganggunya kinerja organisasi secara keseluruhan.

Penurunan kinerja karyawan PDAM Kota Denpasar dapat terlihat pada golongan B,C,D, dan E. Keempat golongan tersebut adalah poin-poin dimana keluhan tersebut diakibatkan karena kesalahan dari karyawan PDAM Kota Denpasar, bukan karena kesalahan dari pelanggan. Tabel 1, dapat dilihat bahwa terdapat dua jenis kesalahan, yaitu kesalahan dari pelanggan dan kesalahan dari karyawan. Misalnya saja untuk golongan B, yaitu air mati, kecil, atau kotor, hal ini disebabkan karena adanya perbaikan di saluran air, biasanya untuk perbaikan ini diperlukan waktu dua sampai tiga hari tergantung tingkat kesulitan, tapi karena karyawan yang melaksanakan perbaikan tersebut tidak puas akan satu sistem yang berlaku di perusahaan, maka karyawan tersebut memperpanjang waktu perbaikan. Apabila dilihat dari segi biaya, ini sangat tidak menguntungkan, karena akan merugikan perusahaan.

Penurunan kinerja karyawan juga merupakan dampak dari tidak puasnya karyawan akan pekerjaannya. Ketidak puasan kerja muncul ketika harapan seseorang tidak terpenuhi. Banyak faktor yang dapat mempengaruhi kepuasan kerja seorang karyawan, yaitu : pekerjaan itu sendiri, gaji/ upah, pengakuan, hubungan antara pimpinan 
Tabel 1.

Data Keluhan Pelanggan Perusahaan Daerah Air Minum (PDAM) Kota Denpasar Tahun 2008 dan 2009

\begin{tabular}{|c|c|c|c|c|}
\hline No & Uraian & Golongan & $\begin{array}{l}\text { Tahun } 2008 \\
\text { (orang ) }\end{array}$ & $\begin{array}{l}\text { Tahun } 2009 \\
\text { (orang ) }\end{array}$ \\
\hline 1 & WM kabur, rusak, mati & A & 1.589 & 1.670 \\
\hline 2 & Air mati, kecil, kotor & $\mathrm{B}$ & 2.025 & 2.350 \\
\hline 3 & $\begin{array}{l}\text { Bocor, doll, BGV, sebelum/sesudah } \\
\text { WM }\end{array}$ & $\mathrm{C}$ & 2.343 & 2.150 \\
\hline 4 & Pemakaian tinggi & $\mathrm{D}$ & 2 & 3 \\
\hline 5 & Berhenti berlangganan & $\mathrm{E}$ & 53 & 39 \\
\hline \multirow[t]{4}{*}{6} & $\begin{array}{l}\text { Lain-lain (pipa melintang, pergantian alat atau } \\
\text { mesin pada WM) }\end{array}$ & $\mathrm{F}$ & 328 & 520 \\
\hline & Total Keluhan Pelanggan & & 6.340 & 6.732 \\
\hline & Total Pelanggan & & 65.786 & 66.583 \\
\hline & Persentase Keluhan Pelanggan (\%) & & 9,64 & 10,11 \\
\hline
\end{tabular}

Sumber : PDAM Kota Denpasar, 2009

Keterangan :

WM : Water Meter

BWM : Bocor di Water Meter.

dan bawahan, dan kesempatan untuk maju (Mathis \& Jackson, 2006). Kepuasan kerja karyawannya akan berimplikasi pada kegairahan kerja yang pada akhirnya berdampak pada kinerja karyawan. Berbagai dampak negatif dapat tercermin dari ketidakpuasan kerja karyawan, seperti mangkir kerja, mogok kerja, kerja lamban, pindah kerja, kerusakan yang disengaja, dan lain - lain yang secara otomatis akan berakibat pada kerugian bagi organisasi. Para pimpinan organisasi dewasa ini harus memberikan perhatian yang serius terhadap kepuasan kerja karyawannya, karena hal ini berkaitan dengan tenaga kerja, produktivitas kerja, dan kelangsungan hidup suatu organisasi.

Kepuasan kerja karyawan dapat lebih ditingkatkan dengan melakukan motivasi terhadap karyawan tersebut. Motivasi dapat berasal dari dalam maupun dari luar diri karyawan itu sendiri. Motivasi akan memberikan semangat bagi karyawan dalam bekerja. Banyak cara yang dapat dilakukan untukmemberikanmotivasi bagikaryawannya, diantaranya dengan memberikan bonus, tunjangan-tunjangan, kenaikan pangkat, karir, dan lain-lain. PDAM Kota Denpasar perlu juga dilakukan motivasi bagi karyawannya agak lebih bersemangat dalam bekerja. Salah satunya adalah dengan mengadakan program pengembangan karir. Hasil wawancara dengan beberapa karyawan, bahwa kondisi kerja di PDAM Kota Denpasar kurang kondusif, hal ini ditandai dengan penilaian kinerja yang subyektif, penempatan karyawan yang terus menerus di satu bidang saja, dan program pengembangan karir yang tidak dilakukan dengan sebagaimana mestinya, seperti pemberian rekomendasi yang tidak adil, dan penyebaran informasi karir yang tidak merata. Hal inilah yang menyebabkan kepuasan kerja karyawan rendah dan akibatnya kinerja karyawan juga menjadi rendah.

PDAM Kota Denpasar melaksanakan program pengembangan karir dengan tujuan untuk mengoptimalkan penggunaan pengetahuan, kemampuan. dan keterampilan yang dimiliki oleh karyawan. Program pengembangan karir juga akan dapat mengurangi turnover karyawan karena merasa kurang diperhatikan oleh manajemen. Program pengembangan karir yang dilakukan oleh Personalia PDAM Kota Denpasar seharusnya dimulai dengan melakukan percobaan karyawan dengan cara karyawan ditempatkan pada departemen atau bagian yang berbeda 
selama beberapa bulan, setelah itu dilakukan penilaian kinerja oleh atasannya masing masing. Setelah itu akan dievaluasi di bagian mana karyawan mendapat nilai paling baik. Dari hasil penilaian yang terbaik tersebut, karena akan diberikan rekomendasi oleh atasan pada bagian tersebut untuk dimutasikan apabila terdapat jabatan yang lowong. Tetapi pada kenyataannya hal ini belum dilaksanakan dengan baik oleh perusahaan.

Keberhasilan dari pengembangan karir, sangat ditentukan oleh perencanaan karir yang matang. Hal senada juga diungkapkan oleh (Tohardi, 2002), bahwa perencanaan karir yang matang merupakan setengah dari keberhasilan. Perencanaan karir untuk karyawan tidak hanya dilakukan oleh pihak manajemen perusahaan, atau yang lebih dikenal dengan istilah perencanaan karir organisasional (organizational Career Planning). Individu atau karyawan juga harus merencanakan karirnya sendiri (individual Career Planning), karyawan harus merencanakan karirnya sendari awal, agar karyawan dapat menetapkan tindakantindakan apa saja yang harus dilakukan untuk mencapai sasaran karir yang diinginkan. Tindakan-tindakan tersebut dapat berupa upaya-upaya dalam pengembangan diri untuk menjadi yang lebih baik. Selama ini, tindakan yang telah dilakukan oleh karyawan PDAM Kota Denpasar dalam perencanaan karimya adalah melanjutkan kembali pendidikannya. Melanjutkan kembali pendidikan bagi karyawan bukan saja untuk mendapatkan ilmu, tapi juga sebagai batu loncatan untuk mencapai sasaran karir yang diinginkan.

Perencanaan karir organisasional dan perencanaan karir individual ini harus saling mendukung dalam pengembangan karir karyawan. Adanya perencanaan karir yang baik akan dapat menumbuhkan semangat bagi karyawan untuk selalu membenahi diri agar menjadi karyawan yang berprestasi tinggi. Adanya perencanaan karir yang matang akan mendorong karyawan untuk terus berkembang baik dari segi intelektualitas juga profesionalitas. (Handoko, 2001) Kinerja adalah proses dimana organisasi mengevaluasi atau menilai prestasi kerja karyawan. (Tika, 2006) Kinerja adalah hasilhasil fungsi pekerjaan atau kegiatan seseorang atau kelompok dalam suatu organisasi yang dipengaruhi oleh berbagai faktor untuk mencapai tujuan organisasi dalam periode waktu tertentu. Kinerja mengacu pada kadar pencapaian tugas-tugas yang membentuk sebuah pekerjaan karyawan. Kinerja merefleksikan seberapa baik karyawan memenuhi persyaratan sebuah pekerjaan.

Pengertian kinerja adalah hasil dari pekerjaan seseorang atau sekelompok orang yang telah memenuhi persyaratan sebuah pekerjaan, dalam suatu perusahaan atau organisasi pada periode waktu tertentu, dalam usaha untuk mencapai tujuan organisasi. Fungsi pekerjaan yang dimaksud yaitu pelaksanaan hasil pekerjaan atau kegiatan seseorang atau sekelompok orang yang menjadi wewenang dan tanggungjawabnya dalam satu organisasi.

Kinerja SDM adalah prestasi kerja atau hasil kerja (output) baik kualitas maupun kuantitas yang dicapai SDM persatuan periode waktu dalam melaksanakan tugas kerjanya sesuai dengan tanggungjawab yang diberikan kepadanya (Mangkunegara \& Prabu, 2006). Kinerja SDM merupakan perilaku nyata yang ditampilkan setiap orang sebagai prestasi kerja yang dihasilkan oleh karyawan sesuai dengan perannya dalam perusahaan (Rivai, 2005). Berdasarkan kedua pendapat tersebut, maka dapat dinyatakan bahwa yang dimaksud dengan kinerja SDM adalah prestasi kerja atau hasil kerja yang dapat dicapai oleh SDM persatuan periode waktu dalam melaksanakan tugas sesuai dengan tanggungjawabnya dalam organisasi.

Luthans \& Frens (2006), memberikan definisi komprehensif dari kepuasan kerja yang meliputi reaksi atau sikap kognitif, afektif, evaluatif dan menyatakan bahwa kepuasan kerja adalah keadaan emosi yang senang atau emosi positif yang berasal dari penilaian pekerjaan atau pengalaman kerja seseorang. Perencanaan karir adalah proses melalui mana seseorang memilih sasaran karir, dan jalur karir ke sasaran tersebut (Handoko, 2001). Perencanaan karir juga didefinisikan sebagai 
suatu perencanaan tentang kemungkinankemungkinan seorang karyawan sebagai individu meniti proses kenaikan pangkat/ jabatan sesuai persyaratan dan kemampuannya (Martoyo, 2000).

Perencanaan karir membuat seorang karyawan mengevaluasi kemampuan dan minatnya, mempertimbangkan kesempatan karir alternatif, menyusun tujuan karir, dan merencanakan aktivitas pengembangan praktis. Fokus utama dari perencanaan karir haruslah selaras antara tujuan pribadi dengan kesempatan yang tersedia secara realistik. Berdasarkan beberapa pendapat diatas, maka dapat: menyatakan bahwa perencanaan karir adalah usaha-usaha yang dilakukan individu untuk mencapai sasaran jabatan yang diinginkan, sesuai dengan persyaratan dan kebijakan yang telah ditetapkan oleh organisasi, serta harus sesuai dengan kemampuan yang dimilikinya.

Perencanaan karir terdiri dari dua elemen utama, yaitu perencanaan karir yang berpusat pada organisasi dan perencanaan karir yang berpusat pada individu. Kedua perencanaan karir ini harus sejalan, jika karyawan menginginkan karir tertentu. Organisasi perlu membantu karyawan dalam perencanaan karir, sehingga keduanya dapat saling memenuhi kebutuhan mereka.

Perencanaan karir organisasional (organisasional Career Planning) berfokus pada pekerjaan dan pengidentifikasian jalan karir yang memberikan kemajuan yang logis atas orang-orang diantara pekerjaan dalam organisasi (Mathis \& Jackson, 2006). Perencanaan karir organisasional mengintegrasikan kebutuhan sumberdaya manusia dan sejumlah aktivitas karir, lebih menitik beratkan pada jenjang atau jalur karir (Simamora, 2004). Perencanaan karir yang berpusat pada organisasi lebih berfokus pada pekerjaan-pekerjaan dan pada pembangunan jalur karir yang menyediakan tempat bagi kemajuan logis dari individu. diantara berbagai pekerjaan yang ada di dalam organisasi. Jalan ini dapat diikuti oleh individu untuk bergerak maju dalam unit-unit organisasi tertentu.

Perencanaan karir individual (individual Career Planning) lebih berfokus pada karir individu daripada kebutuhan organisasional (Mathis \& Jackson, 2006). Perencanaan ini dilakukan oleh para karyawan sendiri dengan menganalisis tujuan dan keterampilan individual mereka. Perencanaan karir individual dimulai dari mengidentifikasi sasaran jabatan yang diinginkan, mencari informasi mengenai jabatan tersebut, menyesuaikan kompetensi yang dimiliki dengan spesifikasi jabatan tersebut, dan melakukan usaha-usaha pengembangan diri.

Fokus utama dari perencanaan karir individual adalah keterampilan individual, karena perencanaan karir individual dilakukan oleh karyawan sendiri. Hal ini mungkin mempertimbangkan situasi baik didalam maupun diluar organisasi yang dapat mengembangkan karir seseorang.

Perencanaan karir baik itu perencanaan karir organisasional maupun individual sangatlah bermanfaat. Dengan adanya perencanaan karir yang baik, niscaya akan menumbuhkan semangat, sebagai motivator bagi karyawan untuk berbenah diri menjadi seorang karyawan yang berprestasi atau berkinerja tinggi serta handal (Tohardi, 2002). Sinergi antara pengembangan karir organisasional ian individual akan menguntungkan bagi perusahaan, hal ini dapat dilihat dari peningkatan kinerja sebagai hasil dari perencanaan karir yang baik.

Hipotesis dalam penelitian ini adalah sebagai berikut 1) Perencanaan karir organisasional berpengaruh terhadap kepuasan kerja karyawan Perusahaan Daerah Air Minum (PDAM) Kota Denpasar, 2) Perencanaan karir individual berpengaruh terhadap kepuasan kerja karyawan Perusahaan Daerah Air Minum (PDAM) Kota Denpasar, 3) Perencanaan karir organisasional berpengaruh terhadap kinerja karyawan Perusahaan Daerah Air Minum (PDAM) Kota Denpasar, 4) Perencanaan karir individual berpengaruh terhadap kinerja karyawan Perusahaan Daerah Air Minum (PDAM) Kota Denpasar, 5) Kepuasan kerja berpengaruh terhadap kinerja karyawan Perusahaan Daerah Air Minum (PDAM) Kota Denpasar. 


\section{METODE PENELITIAN}

Pendekatan penelitian menggunakan tipe penelitian penjelasan (Explanatory Research), yaitu berusaha menjelaskan hubungan kausalitas (causality relation ship) antara variabel perencanaan karir organisasional, perencanaan karir individual, kepuasan kerja, dan kinerja karyawan PDAM Kota Denpasar. Metode yang digunakan dalam penelitian ini adalah metode survey adalah penelitian yang dilakukan pada populasi besar maupun kecil, tetapi data yang dipelajari adalah data dari sampel yang diambil dari populasi tersebut, sehingga ditemukan kejadian-kejadian relatif, distribusi, dan hubungan antar variabel sosiologis maupun psikologis. Data yang berhubungan dengan variabel penelitian dikumpulkan dari perusahaan dengan menggunakan kuisioner, disamping itu dilakukan juga wawancara yang disertai dengan dokumentasi.

Setelah populasi dan sampel ditentukan, maka akan dilanjutkan dengan pengumpulan data dengan melalui metode observasi, wawancara, dan kuisioner berdasarkan instrumen yang telah disusun. Data yang diperoleh akan dianalisis menggunakan alat analisis structural equation modeling (SEM). Dalam SEM terdapat analisis faktor konfirmatori untuk mengkonfirmasi berdasarkan teori dan konsep yang sudah ada terhadap keakuratan instrumen. Hasil analisis kemudian diiterpreasikan dan dilanjutkan dengan menyimpulkan dan memberikan saran. Lokasi penelitian ini adalah Perusahaan Daerah Air Minum (PDAM) Kota Denpasar. Alasan memilih PDAM Kota Denpasar sebagai lokasi penelitian, karena PDAM Kota Denpasar adalah perusahaan daerah yang bertugas untuk menyediakan kebutuhan air minum bagi Kota Denpasar, sebagaimana yang kita ketahui bahwa Kota Denpasar merupakan ibukota dari Pulau Bali dimana semua sektor pembangunan terdapat di Kota Denpasar.

$$
\text { Definisi operasional variabel }
$$

dari masing-masing variabel sebagai berikut. Perencanaan karir organisasional mengintegrasikan kebutuhan sumberdaya manusia dan sejumlah aktivitas karir, lebih menitik beratkan pada jenjang atau jalur karir. Terdapat tujuh indikator yang digunakan untuk mengukur variabel ini, antara lain : pengetahuan jenjang karir, jalur karir, informasi jabatan lowong, informasi kriteria jabatan lowong, pentingnya konseling karir, konseling karir oleh perusahaan, dan konseling karir yang diikuti.

Perencanaan karir individual, adalah perencanaan karir yang terfokus pada usahausaha individu karyawan berdasarkan keinginan, keahlian, dan hasratnya dalam mencapai sasaran karirnya. Terdapat sembilan indikator yang digunakan untuk mengukur variabel perencanaan karir individual, yaitu pentingnya pengetahuan yang dimiliki, pentingnya memperbaiki diri, pentingnya pendidikan karir, pendidikan karir oleh perusahaan, pendidikan karir yang diikuti oleh karyawan, pentingnya menentukan sasaran karir, kemampuan karyawan untuk mencapai sasaran karir, mengikuti jalur karir yang berlaku, jalur karir yang diikuti.

Kepuasan kerja adalah keadaan emosional yang positif yang merupakan hasil dari evaluasi pengalaman kerja seseorang. Ketidak puasan kerja akan muncul apabila harapan seseorang tidak terpenuhi. Terdapat sebelas indikator yang digunakan untuk mengukur variabel kepuasan kerja, yaitu kesempatan naik jabatan, hubungan antar karyawan, kecukupan gaji, kenaikan gaji berkala, peraturan dan prosedur perusahaan, atasan yang kompeten, kesesuaian tugas dan fungsi, kenyamanan ruang kerja, pengakuan atas hasil kerja, komunikasi dan kecukupan tunjangan.

Kinerja karyawan adalah prestasi kerja atau hasil kerja yang dapat dicapai oleh SDM persatuan periode waktu dalam melaksanakan tugas sesuai dengan tanggungjawabnya dalam organisasi. Terdapat sepuluh indikator yang digunakan untuk mengukur variabel kinerja karyawan, yaitu ketepatan waktu dalam menyelesaikan pekerjaan, disiplin dalam melaksanakan tugas, kemauan belajar, teliti dalam melaksanakan tugas, kejujuran/ integrasi, tanggung jawab pada tugas, kepemimpinan, kerjasama, pencapaian target 
kerja dan kemampuan menyelesaikan laporan. Jenis data yang digunakan dalam penelitian ini adalah data kuantitatif dan data kualitatif. Data kuantitatif adalah data yang berbentuk angka-angka yang digunakan dalam penelitian ini. misalnya: data mengenai jumlah keluhan pelanggan, dan data komposisi jumlah karyawan. Data kualitatif adalah data yang tidak dapat dinyatakan dengan angka dan tidak mempunyai satuan hitung. Data kualitatif misalnya tentang gambaran umum perusahaan, struktur organisasi, dan lain-lain.

Sumber data dalam penelitian ini ada dua yaitu sumber primer dan sumber sekunder. Sumber primer adalah data yang diperoleh dari pihak pertama atau responden langsung. Data ini dikumpulkan dari responden berdasarkan survey, penyebaran kuisioner, dan wawancara yang diberikan di lokasi penelitian sesuai dengan apa yang diteliti untuk mendapatkan data yang sesungguhnya/keadaan obyektif yang dirasakan dan dialami oleh karyawan. Sumber sekunder adalah data yang diperoleh dari pihak kedua, data ini tidak langsung diperoleh peneliti dari subyek penelitiannya. Data sekunder dapat berupa data dokumentasi. ataupun laporan-laporan yang sudah tersedia.

Populasi adalah wilayah generalisasi yang terdiri atas : obyek atau subyek yang mempunyai kualitas dan karakteristik tertentu yang ditetapkan oleh peneliti untuk dipelajari dan kemudian ditarik kesimpulannya (Sugiyono, 2004). Populasi dalam penelitian ini adalah seluruh karyawan Perusahaan Daerah Air Minum PDAM) Kota Denpasar yang berjumlah 203 orang.

Sampel adalah sebagian dari jumlah dan karakteristik yang dimiliki oleh populasi (Sugiyono, 2004). Teknik pengambilan sampel dalam penelitian ini menggunakan proportionate stratified random sampling, yaitu pengambilan sampel dari anggota populasi secara acak dan berstrata secara proporsional. Ini dilakukan apabila anggota populasinya tidak sejenis. Sedangkan untuk menentukan ukuran sampelnya, dipergunakan rumus dari Faro Yamane.
$\mathrm{N}=\frac{\mathrm{N}}{\mathrm{N} \cdot \mathrm{d}^{2}+1}$

$\mathrm{n}=$ Jumlah sampel

$\mathrm{N}=$ Jumlah populasi

$\mathrm{d}^{2}=$ Presisi yang ditetapkan

Rumus teknik pengambilan sampel di atas dengan jumlah populasi sebanyak 203 orang dan presisi atau tingkat kesalahan sebesar 5 persen, maka dapat diperhitungkan sebagai berikut:

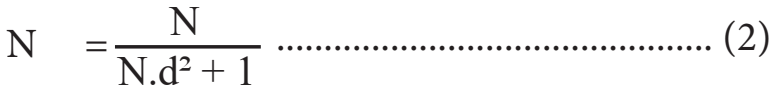

$$
\begin{aligned}
& \mathrm{N}=\frac{203}{203 \cdot(0,02)^{2}+1} \\
& =135 \text { orang }
\end{aligned}
$$
perhitungan di atas berjumlah 135 orang. kemudian dicari pengambilan sampel berstrata dengan rumus $n i=\mathrm{Ni} /$ N.n (Riduwan, 2008)

$\mathrm{ni}=$ jumlah sampel menurut stratum

$\mathrm{n}=$ jumlah sampel seluruhnya

$\mathrm{Ni}=$ jumlah populasi menurut stratum

$\mathrm{N}=$ jumlah populasi seluruhnya

Jumlah total dari jumlah sampel adalah sebesar 135 responden. Hal ini sesuai dengan alat analisis menggunakan program SEM yang mensyaratkan jumlah responden yang berkisar antara 100 - 200 sampel.

Definisi operasional variabel yang telah ditetapkan akan digunakan sebagai pedoman untuk menyusun item-item pertanyaan dalam kuisioner.

Kuisioner tersebut bersifat terstruktur, dimana setiap pertanyaannya telah disediakan alternatif jawabannya. Skala yang digunakan dalam penelitian ini adalah skala likert dengan lima alternatif jawaban, Istij an to (2006) skala likert adalah mengukur tingkat persetujuan atau ketidak setujuan responden terhadap serangkaian pertanyaan yang mengukur suatu obyek. Skala likert digunakan secara spesifik pilihan sangat tidak setuju, tidak setuju. cukup setuju. setuju dan sangat setuju.

Metode yang dipergunakan dalam mengampulkan data dilakukan dengan tiga cara, antara lain sebagai berikut. Kuisioner merupakan metode utama dalam penelitian ini untuk mengumpulkan data. Kuisioner diberikan pada responden untuk dijawab, 
yang mana kuisioner tersebut berisi penilaian tentang variabel-variabel dalam penelitian ini, yaitu perencanaan karir organisasional, perencanaan karir individual, kepuasan kerja, dan kinerja karyawan. Wawancara digunakan sebagai pelengkap dari metode kuisioner yang dilakukan dengan cara tanya jawab secara sistematis dan berlandaskan tujuan dari penelitian ini. Metode wawancara juga digunakan dalam pengumpulan data awal melalui wawancara langsung dengan personalia dan beberapa karyawan PDAM Kota Denpasar mengenai variabel-variabel yang diteliti dalam penelitian ini yaitu : perencanaan karir organisasional, perencanaan karir individual, kepuasan kerja, dan kinerja karyawan PDAM Kota Denpasar. Pengamatan langsung yang dilakukan terhadap perilaku karywan dan kondisi kerja yang diamati mengacu pada perilaku dan kondisi kerja berkaitan dengan perencanaan karir organisasional. perencanaan karir individual, kepuasan kerja dan kinerja karyawan pada PDAM Kota Denpasar.

Penelitian ini menggunakan teknik analisis Structural Equation Modelling (SEM). SEM adalah sekumpulan teknik-teknik statistikal yang memungkinkan pengujian sebuah rangkaian hubungan yang relatif rumit secara simultan. Teknik analisis SEM agar dapat digunakan diperlukan bantuan program SPSS (statistical package for social science\} dan AMOS (analisis of moment structure). SPSS digunakan untuk input data yang diperoleh dari hasil penelitian, sedangkan program AMOS digunakan untuk tampilan hasil penelitian guna melihat hubungan antar variabel.

Penelitian ini dilakukan untuk mengetahui pengaruh perencanaan karir organisasional dan individual terhadap kepuasan kerja dan kinerja karyawan PDAM Kota Denpasar, dengan menerapkan teori dan konsep yang berhubungan dengan perencanaan karir dan kepuasan kerja serta kinerja SDM. Penelitian ini disusun dengan menggunakan SEM (structural equation modeling).

Pemodelan SEM yang lengkap pada dasarnya terdiri dari : Measurement Model (model pengukuran) dan Structural Model (model struktural). Model pengukuran ditujukan untuk mengkonformasi sebuah dimensi atau faktor berdasarkan indikatorindikatornya. Model struktural adalah model mengenai struktur bangunan yang membentuk dan menjelaskan kausalitas antara faktor.

\section{HASIL DAN PEMBAHASAN}

Uji validitas digunakan untuk menunjukkan sejauh mana suatu alat pengukur mengukur apa yang ingin diukur. Jika peneliti menggunakan kuisioner dalam mengumpulkan data, maka kuisioner tersebut harus dapat mengukur apa yang ingin diukur. Penelitian ini menggunakan kuisioner untuk mengumpulkan data, maka setiap butir pertanyaan untuk mengukur suatu variabel perlu diuji dengan menggunakan uji validitas. Uji validitas dilakukan kepada tiga puluh orang responden. Pengujian terhadap validitas menggunakan teknik Pearson Product moment, dengan menggunakan program SPSS for Windows versi 15.0. Tingkat signifikansi yang dipergunakan yaitu, a 0,05. Hal tersebut menandakan bahwa penafsiran para responden terhadap butir-butir pertanyaan dari setiap variabel dalam instrumen penelitian adalah sama. Pada Tabel 2 ditampilkan rekapitulasi uji validitas yang merupakan hasil perhitungan nilai korelasi product moment dari tiap-tiap butir penanyaan dalam kuisioner.

Rekapitulasi dari hasil perhitungan nilai korelasi product moment dari tiap-tiap pertanyaan pada Tabel 2 diperoleh hasil yang besarnya diatas 0,5 . Semua butir pertanyaan dalam kuisioner tersebut dapat dikatakan valid.

Uji reliabilitas digunakan untuk mengukur apakah setiap variabel dapat dipercaya, handal, dan akurat. Uji reliabilitas juga digunakan untuk menunjukkan konsistensi suatu alat pengukur di dalam mengukur gejala yang sama. Uji reliabilitas dilakukan dengan bantuan program SPSS versi 15.0 uji statistik yang dilakukan adalah dengan uji Cronbach Alpha (a). Suatu variabel dikatakan reliabel apabila mempunyai nilai Cronbach Alpha (a) $>0.6$. Rekapitulasi uji 
Tabel 2.

Rekapitulasi Uji Validitas

\begin{tabular}{|c|c|c|c|c|}
\hline Variabel & Indikator & Butir & $\begin{array}{l}\text { Koefisien } \\
\text { Korelasi }\end{array}$ & $\begin{array}{l}\text { Keteran- } \\
\text { gan }\end{array}$ \\
\hline \multirow{7}{*}{$\begin{array}{l}\text { 1. Perencanaan } \\
\text { Karir Organisasi }\end{array}$} & 1.Pengetahuan jenjang karir & XI. 1 & 0,827 & Valid \\
\hline & 2.Jalur karir & $\mathrm{X} 1.2$ & 0,811 & Valid \\
\hline & 3.Informasi jabatan lowong & $\mathrm{X} 1.3$ & 0,872 & Valid \\
\hline & 4.Informasi kriteria jabatan lowong & $\mathrm{X} 1.4$ & 0,904 & Valid \\
\hline & 5.Pentingnya konseling karir & $\mathrm{X} 1.5$ & 0.846 & Valid \\
\hline & 6.Konseling karir oleh perusahaan & $\mathrm{X} 1.6$ & 0,922 & Valid \\
\hline & 7.Konseling karir yang diikuti & $\mathrm{X} 1.7$ & 0.688 & Valid \\
\hline \multirow{9}{*}{$\begin{array}{l}\text { 2. Perencanaan } \\
\text { Karir Individual }\end{array}$} & 1.Pentingnya pengetahuan yang dimiliki & $\mathrm{X} 2.1$ & 0,755 & Valid \\
\hline & 2.Pentingnya memperbaiki diri & $\mathrm{X} 2.2$ & 0,688 & Valid \\
\hline & 3.Pentingnya pendidikan karir & $\mathrm{X} 2.3$ & 0,941 & Valid \\
\hline & 4.Pendidikan karir oleh perusahaan & $\mathrm{X} 2.4$ & 0,796 & Valid \\
\hline & 5.Pendidikan karir yang diikuti oleh karyawan & $\mathrm{X} 2.5$ & 0,911 & Valid \\
\hline & 6.Sasaran karir & $\mathrm{X} 2.6$ & 0,903 & Valid \\
\hline & 7.Kemampuan karyawan & $\mathrm{X} 2.7$ & 0,894 & Valid \\
\hline & 8.Jalur karir yang berlaku & $\mathrm{X} 2.8$ & 0,858 & Valid \\
\hline & 9.Jalur karir vaniz ingin dicapai & $\mathrm{X} 2.9$ & 0,908 & Valid \\
\hline \multirow[t]{10}{*}{ 3.Kepuasan Kerja } & 1.Hubungan antar karyawan & Y1.2 & 0,882 & Valid \\
\hline & 2.Kecukupan gaji & Y1.3 & 0,925 & Valid \\
\hline & 3.Kenaikan gaji berkala & Y1.4 & 0,964 & Valid \\
\hline & 4.Peraturan dan prosedur perusahaan & Y1.5 & 0,953 & Valid \\
\hline & 5.Atasan yang kompeten & Y1.6 & 0,887 & Valid \\
\hline & 6.Kesesuaian tugas dan fungsi & YI.7 & 0,868 & Valid \\
\hline & 7.Kenyamanan ruang kerja & Y1.8 & 0,950 & Valid \\
\hline & 8.Pengakuan atas hasil kerja & Y1.9 & 0,925 & Valid \\
\hline & 9.Komunikasi & Y1.10 & 0,960 & Valid \\
\hline & 10.Kecukupan tunjangan & Y1.11 & 0,903 & Valid \\
\hline 4.Kinerja & 1. Ketepatan waktu menyelesaikan pekerjaan & Y2.1 & 0,897 & Valid \\
\hline \multirow[t]{9}{*}{ Karyawan } & 2. Disiplin dalam melaksanakan tugas & Y2.2 & 0,927 & Valid \\
\hline & 3. Kemauan belajar & Y2.3 & 0,844 & Valid \\
\hline & 4. Teliti dalam melaksanakan tugas & Y2.4 & 0,923 & Valid \\
\hline & 5. Kejujuran/integiasi & Y2.5 & 0,933 & Valid \\
\hline & 6. Tanggung jawab pada tugas & Y2.6 & 0,883 & Valid \\
\hline & 7. Jiwa kepemimpinan & Y2.7 & 0,879 & Valid \\
\hline & 8. Kerjasama & Y2.8 & 0,821 & Valid \\
\hline & 9.Pencapaian target kerja & Y2.9 & 0,790 & Valid \\
\hline & 10. Kemampuan menyelesaikan laporan & Y2.10 & 0,821 & Valid \\
\hline
\end{tabular}

Sumber : Data diolah,2011 
validitas dan reliabilitas dapat dilihat pada Tabel 3.

Tabel 3, dapat dilihat bahwa semua variabel dikatakan reliabel, karena masingmasing variabel memiliki koefisien Cronbach Alpha di atas 0,6.

Ukuran sampel yang hams dipenuhi dalam pemodelan ini adalah minimum berjumlah 100. Dalam penelitian ini sampel yang digunakan berjumlah 135 dengan demikian asumsi pertama yaitu mengenai ukuran sampel sudah terpenuhi dengan baik.

Sebaran data dianalisis terlebih dahulu untuk bisa melihat apakah asumsi normalitas data terpenuhi atau tidak. sehingga dapat diolah lebih lanjut dalam pemodelan SEM. Distribusi data dikatakan normal pada tingkat signifikansi 0,01 jika critical ratio (CR) skewness (kemiringan) tidak lebih dari $\pm 2,58$. Kriteria critical ratio $(\mathrm{CR}) \pm 2,58$ maka dapat dinyatakan bahwa tidak ada bukti kalau data yang digunakan dalam penelitian ini mempunyai sebaran yang tidak normal, karena tidak ada angka CR skew pada Tabel 4 yang lebih dari $\pm 2,58$.

Outliers adalah observasi yang muncul dengan nilai-nilai ekstrim karena kombinasi karakteristik unik yang dimilikinya yang terlihat sangat jauh berbeda dari observasiobservasi lainnya(Ferdinand, 2002). Salah satu cara untuk mendeteksi multivariate outliers adalah dengan menggunakan Uji mahalanobis distance yang menunjukkan seberapa jauh jarak sebuah data dari pusat titik tertentu. Data

Tabel 3.

Rekapitulasi Uji Reliabilitas

\begin{tabular}{lll}
\hline Variabel & Koefisien Alpha & Keterangan \\
\hline $\begin{array}{l}\text { Perencanaan } \\
\text { Karir Organisasional }\end{array}$ & 0,924 & Reliabel \\
$\begin{array}{l}\text { Perencanaan } \\
\text { Karir Individual }\end{array}$ & 0,963 & Reliabel \\
Kepuasan Kerja & 0,976 & \\
Kinerja Karyawan & 0,962 & Reliabel \\
Sumber : Data diolah,2011 & & Reliabel \\
\hline
\end{tabular}

Tabel 4.

Hasil Uji Normalitas Data

\begin{tabular}{|c|c|c|c|c|c|c|c|}
\hline Variabel & Indikator & $\min$ & $\max$ & skew & c.r. & Kurtosis & c.r. \\
\hline $\mathrm{Y} 2.10$ & $\begin{array}{l}\text { Kemampuan menyelesaikan } \\
\text { laporan }\end{array}$ & 1.000 & 5.000 & -.433 & -2.053 & -1.128 & -2.675 \\
\hline Y2.9 & Pencapaian target kerja & 1.000 & 5.000 & -.330 & -1.564 & -1.105 & -2.620 \\
\hline $\mathrm{Y} 2.8$ & Kerjasama & 1.000 & 5.000 & -.349 & -1.656 & -1.257 & -2.982 \\
\hline Y2.7 & Jiwa kepemimpinan & 1.000 & 5.000 & -.169 & -.803 & -1.098 & -2.603 \\
\hline Y2.6 & Tanggung jawab pada tugas & 1.000 & 5.000 & -.333 & -1.579 & -1.086 & -2.575 \\
\hline Y2.5 & Kejujuran atau integrasi & 1.000 & 5.000 & -.420 & -1.994 & -1.087 & -2.579 \\
\hline $\mathrm{Y} 2.4$ & Teliti dalam melaksanakan tugas & 1.000 & 5.000 & -.330 & -1.564 & -1.044 & -2.476 \\
\hline $\mathrm{Y} 2.3$ & Kemauan belajar & 1.000 & 5.000 & -.278 & -1.320 & -1.045 & -2.478 \\
\hline Y2.2 & $\begin{array}{l}\text { Disiplin dalam melaksanakan } \\
\text { tugas }\end{array}$ & 1.000 & 5.000 & -.239 & -1.135 & -1.209 & -2.867 \\
\hline Y2.1 & $\begin{array}{l}\text { Ketepatan waktu menyelesaikan } \\
\text { pekerjaan }\end{array}$ & 1.000 & 5.000 & -.355 & -1.682 & -1.009 & -2.392 \\
\hline Y1.10 & Kecukupan tunjangan & 1.000 & 5.000 & -.339 & -1.609 & -.984 & -2.333 \\
\hline Y1.9 & Komunikasi & 1.000 & 5.000 & -.349 & -1.657 & -1.007 & -2.389 \\
\hline
\end{tabular}




\begin{tabular}{|c|c|c|c|c|c|c|c|}
\hline Variabel & Indikator & $\min$ & $\max$ & skew & c.r. & Kurtosis & c.r. \\
\hline Y1.8 & Pengakuan atas hasil kerja & 1.000 & 5.000 & -.168 & -.799 & -1.128 & -2.676 \\
\hline Y1.7 & Kenyamanan ruang kerja & 1.000 & 5.000 & -.203 & -.961 & -1.112 & -2.638 \\
\hline Y1.6 & Kesesuaian tugas dan fungsi & 1.000 & 5.000 & -.195 & -.927 & -1.311 & -3.110 \\
\hline yl.5 & Atasan yang kompeten & 1.000 & 5.000 & -.300 & -1.422 & -1.131 & -2.683 \\
\hline yl.4 & $\begin{array}{l}\text { Peraturan dan prosedur } \\
\text { perusahaan }\end{array}$ & 1.000 & 5.000 & -.323 & -1.531 & -1.118 & -2.653 \\
\hline yl.3 & Kenaikan gaji berkala & 1.000 & 5.000 & -.278 & -1.318 & -1.202 & -2.851 \\
\hline yl.2 & Kecukupan gaji & 1.000 & 5.000 & -.133 & -.632 & -1.213 & -2.877 \\
\hline Y1.1 & Hubungan antar karyawan & 1.000 & 5.000 & -.202 & -.958 & -.877 & -2.079 \\
\hline $\mathrm{X} 2.9$ & Jalur karir yang ingin dicapai & 1.000 & 5.000 & -.343 & -.1 .625 & -.948 & -2.079 \\
\hline $\mathrm{x} 2.8$ & Jalur karir yang berlaku & 1.000 & 5.000 & -.403 & -1.914 & -.945 & -2.249 \\
\hline $\mathrm{x} 2.7$ & Kemampuan karyawan & 1.000 & 5.000 & -.525 & -2.488 & -.841 & -1.994 \\
\hline $\mathrm{x} 2.6$ & Sasaran karir & 1.000 & 5.000 & -.236 & -1.119 & -.782 & -1.855 \\
\hline $\mathrm{x} 2.5$ & $\begin{array}{l}\text { Pendidikan karir yang diikuti } \\
\text { oleh karyawan }\end{array}$ & 1.000 & 5.000 & -.456 & -2.162 & -.695 & -1.648 \\
\hline $\mathrm{x} 2.4$ & $\begin{array}{l}\text { Pendidikan karir oleh } \\
\text { perusahaan }\end{array}$ & 1.000 & 5.000 & -.295 & -1.398 & -.721 & -1.710 \\
\hline $\mathrm{x} 2.3$ & Pentingnya pendidikan & 1.000 & 5,000 & -.279 & -1.325 & -.947 & -2.245 \\
\hline $\mathrm{x} 2.1$ & $\begin{array}{l}\text { Pentingnya pengetahuan yang } \\
\text { dimiliki }\end{array}$ & 1.000 & 5.000 & -.474 & -2.247 & -.857 & -2.033 \\
\hline $\mathrm{x} 2.2$ & Pentingnya memperbaiki diri & 1.000 & 5.000 & -.358 & -1.699 & -1.097 & -2601 \\
\hline $\mathrm{xl} .7$ & Konseling karir yang diikuti & 1.000 & 5.000 & -.177 & -.839 & -1.130 & -2.680 \\
\hline $\mathrm{xl} .6$ & $\begin{array}{l}\text { Konseling karir oleh } \\
\text { perusahaan }\end{array}$ & 1.000 & 5.000 & -.134 & -.637 & -853 & -2.023 \\
\hline $\mathrm{xl} .5$ & Pentingnya konseling karir & 1.000 & 5.000 & -.117 & -.555 & -.907 & -2.152 \\
\hline xl.4 & $\begin{array}{l}\text { Informasi kriteria jabatan } \\
\text { lowong }\end{array}$ & 1.000 & 5.000 . & -.239 & -1.133 & -.916 & -2.171 \\
\hline $\mathrm{xl} .3$ & Informasi jabatan lowong & 1.000 & 5.000 & -.374 & -1.776 & -.960 & -2.276 \\
\hline xl.1 & Pengetahuan jenjang karir & 1.000 & 5.000 & -.416 & -1.972 & -.858 & -2035 \\
\hline $\mathrm{xl} 2$ & Jalur karir & 1.000 & 5000 & -.249 & -1.181 & -.930 & -2.205 \\
\hline $\begin{array}{l}\text { Multi } \\
\text { variabel }\end{array}$ & & & & & & 58.410 & 6.001 \\
\hline
\end{tabular}

dikatakan outlier jika mempunyai nilai pi dan $\mathrm{p} 2$ yang $<0,05$. Berdasarkan hasil output, dapat dilihat bahwa dari 135 data responden, terdapat dua data yang dikategorikan sebagai outlier yaitu responden nomor 82 dan 27. Dalam penelitian ini gejala outliers yang ditemukan pada observasi tersebut tidak dihilangkan dari analisis selanjutnya, karena tidak ada alasan khusus untuk profil responden tersebut yang menyebabkan ia harus dikeluarkan dari analisis ini.

Multikoleniaritas dapat dideteksi dari determinan matriks kovarians yang sangat kecil memberi indikasi adanya problem multikoleniaritas dan singularitas (Ferdinand, 2002). Nilai output determinant of sample covariance matrix adalah 0,046 Nilai tersebut jauh dari nol, sehingga dapat dinyatakan tidak ada multikolinearitas dan singularitas. Dengan demikian data dalam penelitian ini layak untuk 
Tabel 5.

Hasil Uji Reliabilitas Konstruk

\begin{tabular}{|c|c|c|c|c|c|c|c|}
\hline $\begin{array}{c}\text { Konstruk } \\
\text { (1) }\end{array}$ & $\begin{array}{c}\text { Indktr } \\
(2)\end{array}$ & $\begin{array}{c}\text { Std.Load } \\
(3)\end{array}$ & $\begin{array}{l}\text { Std Load) } \\
\text { (4) }\end{array}$ & $\begin{array}{c}\left(\text { L Loaen }^{2}\right) \\
(5)\end{array}$ & $\begin{array}{l}\text { Eror } \\
(6)\end{array}$ & $\begin{array}{c}\text { S Eror } \\
(7)\end{array}$ & $\begin{array}{l}\text { Const. Rel } \\
(5):(5+7)\end{array}$ \\
\hline \multirow{7}{*}{$\begin{array}{l}\text { Perencanaan karir } \\
\text { organisasional }\end{array}$} & $\mathrm{X} 1.1$ & 0,744 & 5,458 & 29,789 & 0,553 & 4,271 & 0,874 \\
\hline & $\mathrm{X} 1.2$ & 0,821 & & & 0,674 & & \\
\hline & $\mathrm{X} 1.3$ & 0.768 & & & 0,589 & & \\
\hline & $\mathrm{X} 1.4$ & 0,857 & & & 0,735 & & \\
\hline & $\mathrm{X} 1.5$ & 0.714 & & & 0.510 & & \\
\hline & $\mathrm{X} 1.6$ & 0,814 & & & 0,662 & & \\
\hline & $\mathrm{X} 1.7$ & 0,740 & & & 0,548 & & \\
\hline \multirow{9}{*}{$\begin{array}{l}\text { Perencanaan karir } \\
\text { individu }\end{array}$} & $\mathrm{X} 2.1$ & 0,771 & 8,351 & 69,739 & 0,594 & 6,454 & 0.915 \\
\hline & $\mathrm{X} 2.2$ & 0.759 & & & 0.576 & & \\
\hline & $\mathrm{X} 2.3$ & 0,853 & & & 0,727 & & \\
\hline & $\mathrm{X} 2.4$ & 0.836 & & & 0.698 & & \\
\hline & $\mathrm{X} 2.5$ & 0,897 & & & 0.805 & & \\
\hline & $\mathrm{X} 2.6$ & 0,870 & & & 0.758 & & \\
\hline & $\mathrm{X} 2.7$ & 0.627 & & & 0,393 & & \\
\hline & $\mathrm{X} 2.8$ & 0,549 & & & 0,301 & & \\
\hline & $\mathrm{X} 2.9$ & 0,784 & & & 0,614 & & \\
\hline \multirow[t]{10}{*}{ Kepuasan kerja } & Y1.I & 0.814 & 9,091 & 82.646 & 0.663 & 7,539 & 0.916 \\
\hline & Y1.2 & 0,760 & & & 0,577 & & \\
\hline & Y1.3 & 0.897 & & & 0.804 & & \\
\hline & Y1.4 & 0,881 & & & 0,776 & & \\
\hline & Y1.5 & 0.842 & & & 0.710 & & \\
\hline & Y1.6 & 0.832 & & & 0.692 & & \\
\hline & Y1.7 & 0,819 & & & 0.670 & & \\
\hline & Y1.8 & 0.852 & & & 0.726 & & \\
\hline & Y1.9 & 0,875 & & & $0,76-6$ & & \\
\hline & Y1.10 & 0,781 & & & 0.611 & & \\
\hline \multirow[t]{10}{*}{ Kinerja karyawan } & Y2.1 & 0,866 & 8,541 & 72,948 & 0,751 & 7,335 & 0,908 \\
\hline & Y2.2 & 0,857 & & & 0.734 & & \\
\hline & Y2.3 & 0.891 & & & 0,794 & & \\
\hline & Y2.4 & 0.949 & & & 0.901 & & \\
\hline & Y2.5 & 0.927 & & & 0.860 & & \\
\hline & Y2.6 & 0,914 & & & 0.835 & & \\
\hline & Y2.7 & 0.801 & & & 0.641 & & \\
\hline & Y2.8 & 0.777 & & & 0.604 & & \\
\hline & Y2.9 & 0,758 & & & 0.574 & & \\
\hline & Y2.9 & 0,801 & & & 0,641 & & \\
\hline
\end{tabular}


digunakan.

Reliabilitas adalah ukuran mengenai konsistensi internal dari indikator-indikator sebuah konstruk yang menunjukkan derajat sampai sejauh mana masing-masing indikator itu mengindikasikan sebuah konstruk laten. Sebuah alat ukur dikatakan reliabel bila nilai construe reliability $>0,70$ atau variance extract paling sedikit 0,50 . Nilai variance extract yang tinggi menunjukkan bahwa indikator-indikator tersebut telah mewakili secara baik konstruk laten yang dikembangkan. Pendekatan yang digunakan dalam menilai reliabilitas konstruk adalah composite reliability.

Tabel 5, terlihat bahwa nilai reliabilitas untuk masing-masing konstruk lebih dari 0,70. Dengan demikian dapat dinyatakan bahwa indikator dari masing-masing konstruk adalah reliabel.

Uji discriminant validity digunakan jika ada dua atau lebih konstruk dalam satu model, maka seharusnya setiap konstruk mempunyai keunikan tersendiri dan tidak berhubungan dengan konstruk yang lain.

Tabel 6.

Hasil Uji Discriminant Validity

\begin{tabular}{lll}
\hline Indikator dan konstruk & Kordasi $(\mathrm{r})$ & Kordasi kuadrat $(\mathrm{r} ")$ \\
\hline $\mathrm{y} 1 \longrightarrow \mathrm{x} 1$ & 0,459 & 0,2106 \\
$\mathrm{y} 1 \longrightarrow \mathrm{x} 2$ & 0,330 & 0,1089 \\
$\mathrm{y} 2 \longrightarrow \mathrm{x} 1$ & 0,220 & 0,0484 \\
$\mathrm{y} 2 \longrightarrow \mathrm{x} 2$ & 0,242 & 0,0585 \\
$\mathrm{y} 1 \longrightarrow \mathrm{y} 1$ & 0,239 & 0,0571 \\
\hline
\end{tabular}

Sumber : Data diolah,2011

Tabel 7.

Hasil Uji Validitas Indikator Masing-Masing Konstruk

\begin{tabular}{|c|c|c|c|c|c|}
\hline $\begin{array}{l}\text { Indikator dan } \\
\text { konstruk }\end{array}$ & Unstd. Estimate & Std. Estimate & S.E & C.R & $\mathrm{P}$ \\
\hline $\mathrm{X} 1.1 \longmapsto \mathrm{X} 1$ & 0,978 & 0,744 & 0.100 & 9,785 & 0,000 \\
\hline $\mathrm{X} 1.2 \longleftrightarrow \mathrm{X} 1$ & 1,000 & 0,821 & & & \\
\hline $\mathrm{X} 1.3 \longleftrightarrow \mathrm{X} 1$ & 1,049 & 0,768 & 0,104 & 10,127 & 0.000 \\
\hline $\mathrm{X} 1.4 \longmapsto \mathrm{X} 1$ & 1,071 & 0,857 & 0,091 & 11,763 & 0.000 \\
\hline $\mathrm{X} 1.5 \longleftrightarrow \mathrm{X} 1$ & 0,924 & 0,714 & 0,100 & 9.254 & 0.000 \\
\hline $\mathrm{X} 1.6 \longmapsto \mathrm{X} 1$ & 1,010 & 0,816 & 0,092 & 10,926 & 0.000 \\
\hline $\mathrm{X} 1.7 \longleftrightarrow \mathrm{X} 1$ & 0,974 & 0,740 & 0,101 & 9,621 & 0.000 \\
\hline $\mathrm{X} 2.1 \longmapsto \mathrm{X} 2$ & 0,997 & 0,771 & 0,105 & 9,517 & 0,000 \\
\hline $\mathrm{X} 2.2 \longmapsto \mathrm{X} 2$ & 1,000 & 0,759 & & & \\
\hline $\mathrm{X} 2.3 \longleftrightarrow \mathrm{X} 2$ & 1,028 & 0,853 & 0,096 & 10.681 & 0.000 \\
\hline $\mathrm{X} 2.4 \longleftrightarrow \mathrm{X} 2$ & 1,001 & 0,836 & 0.096 & 10,402 & 0.000 \\
\hline $\mathrm{X} 2.5 \longleftrightarrow \mathrm{X} 2$ & 1,136 & 0.897 & 0.100 & 11,367 & 0.000 \\
\hline $\mathrm{X} 2.6 \longleftrightarrow \mathrm{X} 2$ & 1,034 & 0,870 & 0,095 & 10.893 & 0.000 \\
\hline $\mathrm{X} 2.7 \longleftrightarrow \mathrm{X} 2$ & 0,779 & 0,627 & 0,104 & 7,417 & 0.000 \\
\hline $\mathrm{X} 2.8 \longleftrightarrow \mathrm{X} 2$ & 0.658 & 0,549 & 0.102 & 6,428 & 0.000 \\
\hline $\mathrm{X} 2.9 \longleftrightarrow \mathrm{X} 2$ & 1,031 & 0,784 & 0.107 & 9,600 & 0.000 \\
\hline $\mathrm{Y} 1.1 \longleftrightarrow \mathrm{Y} 1$ & 0,819 & 0,814 & 0,065 & 12,532 & 0.000 \\
\hline Y1.2 & 0,845 & 0,760 & 0,076 & 11,098 & 0.000 \\
\hline $\mathrm{Y} 1.3 \longleftrightarrow \mathrm{Y} 1$ & 1,039 & 0,897 & 0.068 & 15.250 & 0.000 \\
\hline
\end{tabular}




\begin{tabular}{|c|c|c|c|c|c|}
\hline $\begin{array}{l}\text { Indikator dan } \\
\text { konstruk }\end{array}$ & Unstd. Estimate & Std. Estimate & S.E & C.R & $\mathrm{P}$ \\
\hline $\mathrm{Y} 1.4 \longleftrightarrow \mathrm{Y} 1$ & 1,038 & 0,881 & 0,071 & 14.692 & 0.000 \\
\hline $\mathrm{Y} 1.5 \longleftrightarrow \mathrm{Y} 1$ & 0,900 & 0,842 & 0,067 & 13,349 & 0.000 \\
\hline $\mathrm{Y} 1.6 \longleftrightarrow \mathrm{Y} 1$ & 0,939 & 0,832 & 0,072 & 13,070 & 0.000 \\
\hline $\mathrm{Y} 1.7 \longleftrightarrow \mathrm{Y} 1$ & 0.884 & 0,819 & 0.070 & 12,676 & 0.000 \\
\hline $\mathrm{Y} 1.8 \longmapsto \mathrm{Y} 1$ & 0.929 & 0,852 & 0,068 & 13.724 & 0.000 \\
\hline $\mathrm{Y} 1.9 \longleftrightarrow \mathrm{Y} 1$ & 1,000 & 0,875 & & & \\
\hline $\mathrm{Y} 2.1 \longmapsto \mathrm{Y} 2$ & 1,000 & 0,866 & & & \\
\hline $\mathrm{Y} 2.2 \longmapsto \mathrm{Y} 2$ & 0,925 & 0,857 & 0,068 & 13,685 & 0.000 \\
\hline $\mathrm{Y} 2.3 \longleftrightarrow \mathrm{Y} 2$ & 1,002 & 0,891 & 0.068 & 14,807 & 0.000 \\
\hline $\mathrm{Y} 2.4 \longleftrightarrow \mathrm{Y} 2$ & 1,052 & 0,949 & 0,062 & 17,066 & 0.000 \\
\hline $\mathrm{Y} 2.5 \longleftrightarrow \mathrm{Y} 2$ & 1,100 & 0,927 & 0,068 & 16,158 & 0.000 \\
\hline $\mathrm{Y} 2.6 \longmapsto \mathrm{Y} 2$ & 1,059 & 0,914 & 0,068 & 15,639 & 0.000 \\
\hline $\mathrm{Y} 2.7 \longleftrightarrow \mathrm{Y} 2$ & 0,889 & 0,801 & 0,074 & 12,071 & 0.000 \\
\hline $\mathrm{Y} 2.8 \longleftrightarrow \mathrm{Y} 2$ & 0,943 & 0,777 & 0,082 & 11,443 & 0.000 \\
\hline $\mathrm{Y} 2.9 \longleftrightarrow \mathrm{Y} 2$ & 0,834 & 0,758 & 0,076 & 10,951 & 0.000 \\
\hline $\mathrm{Y} 2.10 \leftrightarrow \mathrm{Y} 2$ & 0,969 & 0,801 & 0,081 & 12,030 & 0.000 \\
\hline
\end{tabular}

Tabel 8

Goodness of Fit Indexes Model 1 Persamaan Struktural

\begin{tabular}{llll}
\hline Goodness of Fit Indexs & Cut of Value & Hasil Model & Keterangan \\
\hline X2-Chi-Square & Diharapkan kecil & 1033,622 & Besar \\
Probability $(P)$ & $\geq 0,05$ & 0,000 & Marginal \\
GFI & $\geq 0,90$ & 1,485 & Marginal \\
CMIN/DF & $\leq 2,00$ & 0,723 & Baik, \\
TLI & $\geq 0,95$ & 0,925 & Marginal \\
CFI & $\geq 0,95$ & 0,930 & Marginal \\
RMSEA & $\leq 0,08$ & 0,060 & Baik \\
AGF1 & $\geq 0,90$ & 0,690 & Marginal \\
\hline Sumber:Data
\end{tabular}

Uji diskriminan mencari seberapa besar dua variabel berbeda.

Tabel 6 terlihat bahwa angka (r2) yakni 21,06 persen, 10,89 persen, 4,84 persen, 5,85 persen dan 5,71 persen semuanya masih dibawah angka variance extracted, yakni 63,55 persen. 58,67 persen, 68.61 persen dan 73.34 persen. Hal ini membuktikan bahwa hubungan antar konstruk adalah lemah, yang menunjukkan keempat konstruk memang dapat dibedakan satu dengan yang lain (diskriminan) dengan demikian, keempat konstruk telah lolos uji diskriminan.

Validitas dan unidimensionalitas konstruk dapat diuji dari hasil model pengukuran regression weights melalui teknik confirmatory factor analysis. Indikatorindikator yang mempunyai loading factor < 0,5 dinyatakan tidak valid dan dikeluarkan dari model ini (Ghozali \& Chairi., 2007). Signifikan tidaknya suatu indikator dapat juga dilihat dari nilai Probability (P) pada hasil uji regression weights tersebut. Jika nilai $\mathrm{P}$ melebihi 0,05 maka indikator tersebut tidak signifikan

Tabel 7, menunjukkan hasil uji validitas indikator, hasil loading factor (standardized estimate regression-weights) seluruh indikator 
Tabel 9

Goodness of Fit Indexes Model 2 Persamaan Struktural

\begin{tabular}{llll}
\hline Goodness of Fit Indexs & Cut of Value & Hasil Model & Keterangan \\
\hline X2-Chi-Square & Diharapkan kecil & 624,015 & Kecil \\
Probability $(P)$ & $\geq 0,05$ & 0,111 & Baik \\
GFI & $\geq 0,90$ & 0,809 & Marginal \\
CMIN/DF & $\leq 2,00$ & 1,072 & Baik, \\
TLI & $\geq 0,95$ & 0,990 & Baik \\
CFI & $\geq 0,95$ & 0.990 & Baik \\
RMSEA & $\leq 0,08$ & 0,023 & Baik \\
AGFI & $\geq 0,90$ & 0,781 & Marginal \\
\hline Sumber: Data diolah,2011 & & &
\end{tabular}

Sumber : Data diolah,2011

dari masing-masing konstruk lebih besar dari 0,5 dan nilai Probability (P) masing-masing indikator kurang dari 0,05. Dengan demikian dapat dinyatakan bahwa seluruh indikator dari masing-masing konstruk adalah valid.

Hasil uji kesesuaian pada model persamaan struktural yang terlihat pada Tabel 8 menunjukkan bahwa semua kriteria goodness of fit bernilai baik atau mendekati baik (marginal), hal ini ditunjukkan dengan nilai X2-Chi-square sebesar 1033,622 dan Probability 0,000, nilai ini lebih kecil dari kriteria yang ditetapkan yaitu $>0,05$. Indeks GFI dengan nilai 0,723 . nilai berada di kriteria marginal (mendekati baik), karena berdasarkan kriteria, rentang nilai dari GFI adalah 0 (poor) sampai dengan 1 (perfect ft), nilai yang disarankan adalah $>0.90$. tapi karena pada hasil Model menunjukkan nilai 0,723. nilai ini masih dalam rentang 0 sampai dengan 1 , jadi indeks ini masih dapat diterima. Indeks AGFI dengan nilai 0,690 berada di kriteria marginal (mendekati baik). Selanjutnya indeks CMIN/DF dengan nilai 1,485, nilai ini berada pada kriteria baik. karena nilai ini menunjukkan nilai yang $<2,00$. Nilai RMSEA pada Model menunjukkan nilai 0,060 , indeks ini berada pada kriteria baik, karena telah sesuai dengan kriteria yang telah ditetapkan yaitu $<0,08$. Indeks TLI menunjukkan nilai 0,925 dan indeks CFI dari hasil pada Model menunjukkan nilai 0,930 , kedua indeks ini berada pada kriteria marginal, karena belum sesuai dengan kriteria yang ditetapkan yaitu sebesar $>0,95$, indeks ini sangat dianjurkan digunakan karena indeks ini relatif tidak

sensitif terhadap besarnya sampel dan dan kurang dipengaruhi oleh kerumitan model, sehingga model ini telah belum memenuhi syarat goodness of fit dilihat dari nilai TI.I (Tucker Lewiss Indeks) dan CFI (Comperatif Fit Index).

Interpretasi terhadap nilai residual. Model berbasis teori ini harus dievaluasi untuk melihat apakah model ini dapat diterima atau tidak. Untuk mengevaluasi dilakukan dengan melakukan pengamatan pada nilainilai standardized residual covariance. Berdasarkan pengamatan, dapat dilihat bahwa tidak ada variabel yang mempunyai nilai residual $> \pm 2,58$. Hal ini menunjukkan bahwa Model ini dapat diterima dan tidak perlu dilakukan modifikasi.

Interpretasi terhadap indeks modifikasi. Indeks modifikasi adalah sebuah indeks yang digunakan sebagai pedoman dalam melakukan modifikasi terhadap model yang diajukan. Indeks ini memberi penurunan pada nilai chi-square. Variabel-variabel yang diestimasi adalah variabel yang mempunyai nilai paling besar diantara variabel lainnya. Dari hasil komputasi program AMOS terhadap indeks modifikasi covariance dan indeks modifikasi regression weights dalam model penelitian ini dapat dilihat bahwa variabel XI (perencanaan karir organisasional) dan X2 (perencanaan karir individual) mempunyai indeks modifikasi yang paling besar, yaitu 5,279 (XI) dan 4,502 (X2), apabila variabel ini diestimasi maka akan terjadi penurunan nilai chi-squre.

Setelah dilakukan modifikasi dan 
Tabel 10.

Estimasi Regression Weights Model Persamaan Struktural Pengaruh Perencanaan Karir Organisasional dan Individual terhadap Kepuasan Kerja dan Kinerja Karyawan PDAM Kota Denpasar

\begin{tabular}{llllll}
\hline Konstruk & Unstd. Estimate & Std. Estimate & S.E & C.R & P \\
\hline $\mathrm{YK} \longleftrightarrow \mathrm{X} 1$ & 0,606 & 0,499 & 0,119 & 5,104 & 0,000 \\
$\mathrm{YK} \longleftrightarrow \mathrm{X} 2$ & 0,336 & 0,285 & 0,109 & 3,092 & 0,002 \\
$\mathrm{Y} 2 \longleftrightarrow \mathrm{X} 1$ & 0,287 & 0,238 & 0,139 & 2,065 & 0,039 \\
$\mathrm{Y} 2 \longleftrightarrow \mathrm{X} 2$ & 0,286 & 0,244 & 0,120 & 2,375 & 0,018 \\
$\mathrm{Y} 2 \longleftrightarrow \mathrm{Y} 1$ & 0,230 & 0,231 & 0,107 & 2,149 & 0.032 \\
\hline
\end{tabular}

Tabel 11.

Pengaruh Langsung, Pengaruh Tidak Langsung, dan Pengaruh Total Perencanaan Karir Organisasional dan Individual terhadap Kepuasan Kerja dan Kinerja Karyawan PDAM Kota Denpasar

\begin{tabular}{lll}
\hline Tipe Pengaruh & Konstruk & Standardized Estimate \\
\hline Pengaruh langsung & X1-Y1 & 0,499 \\
& X2-Y1 & 0,285 \\
& X1-Y2 & 0,238 \\
& X2-Y2 & 0,244 \\
Yengaruh tidak langsung & X1-Y2 & 0,231 \\
Pengaruh total & X2-Y2 & 0.116 \\
& X1-Y1 & 0,066 \\
& X2-Y1 & 0,499 \\
& X1-Y2 & 0.354 \\
& X2-Y2 & 0.310 \\
& Y1-Y2 & 0.231 \\
\hline
\end{tabular}

Sumber : Data diolah,2011

Model 1 ke Model 2, model tersebut sudah bisa dinyatakan sesuai dengan kriteria goodness of fit. Adapun indeks kesesuaian (goodness of fit) model persamaan struktural adalah seperti tampak pada Tabel 9.

Nilai goodness of fit pada Tabel 9, dapat dinyatakan bahwa Model 2 sebagai fit model, ini karena indeks goodness of fit pada Model 2 lebih baik dibandingkan dengan Mode! 1. X2-Chi-Square yang sebelumnya 1033,622 turun menjadi 624,015. Probability (P) yang sebelumnya 0,000 naik menjadi 0,111, dimana nilai Probability ini jauh di atas 0.05 . Indeks-indeks yang lainnya seperti GFI vane sebelumnya 0.723 naik menjadi 0.809 . CMIN/DF sebelumnya besar 1.485 turun menjadi 1.072 . TLI vane sebelumnya 0.925 naik menjadi 0,990. nilai CFI vane sebelumnya 0.930 naik menjadi 0.990. RMSEA yang sebelumnya 0.060 turun menjadi 0.023 dan AGFI vane sebelumnya 0.690 naik menjadi 0.781. Walaupun indeks GFI dan AGFI masih dalam kategori marginal, tetapi telah diimbangi indeks-indeks vans lain vane telah berada dalam kategori baik, sehingga dapat dinyatakan bahwa model ini sudah fit dengan data.

Tabel 10, dapat diketahui bahwa berdasarkan hasil estimasi standardized regression weights, pengaruh perencanaan karir organisasional (XI) terhadap kepuasan kerja (Y1) adalah sebesar 0,606 dengan tingkat signifikansi sebesar 0,000 . Pengaruh perencanaan karir individual (X2) terhadap 
kepuasan kerja (Y1) adalah sebesar 0,285 dengan tingkat signifikansi sebesar 0.002 . Pengaruh perencanaan karir organisasional (XI) terhadap kinerja karyawan (Y2) adalah sebesar 0,238 dengan tingkat signifikansi sebesar 0.039. Pengaruh perencanaan karir individual (X2) terhadap kinerja karyawan (Y2) adalah sebesar 0,244 dengan tingkat signifikansi sebesar 0,018. Pengaruh motivasi kerja (X2) terhadap kinerja karyawan (Y2) adalah sebesar 0,231 dengan tingkat signifikansi sebesar 0.032 .

Tabel 11, dapat diketahui pengaruh langsung,pengaruhtidaklangsungdanpengaruh total dari perencanaan karir organisasional dan individual terhadap motivasi kerja dan kinerja karyawan. Pengaruh langsung dari masing-masing variabel yaitu : perencanaan karir organisasional (XI) terhadap kepuasan kerja (Y1) adalah sebesar 0.499 , perencanaan karir individual (X2) terhadap kepuasan kerja (Y1) adalah sebesar 0.285, perencanaan karir organisasional (XI) terhadap kinerja karyawan (Y2) adalah sebesar 0,238, perencanaan karir individual (X2) terhadap kinerja karyawan (Y2) adalah sebesar 0,244, dan kepuasan kerja (Y1) terhadap kinerja karyawan (X2) adalah sebesar 0,231.

Pengaruh tidak langsung dari perencanaan karir organisasional (XI) terhadap kinerja karyawan (X2) melalui variabel kepuasan kerja adalah sebesar 0,116 dan pengaruh tidak langsung dari perencanaan karir individual (X2) terhadap kinerja karyawan (Y2) melalui variabel kepuasan kerja adalah sebesar 0,066.

Pengaruh total dari perencanaan karir organisasional (XI) terhadap kepuasan kerja (Y1) adalah sebesar 0,499. Pengaruh perencanaan karir individual (X2) terhadap kepuasan kerja (Y1) adalah sebesar 0,285. Pengaruh perencanaan karir organisasional (X1) terhadap kinerja karyawan (Y2) adalah sebesar 0,354, pengaruh perencanaan karir individual (X2) terhadap kinerja karyawan (Y2) adalah sebesar 0,310, dan pengaruh kepuasan kerja (Y1) terhadap kinerja karyawan (Y2) adalah sebesar 0,231.

Berdasarkan output estimasi regression weights pada Tabel 7. maka dapat dilakukan pengujian hipotesis dalam penelitian ini yaitu sebagai berikut.

Hipotesis 1. Bahwa perencanaan karir organisasional terpengaruh signifikan terhadap kepuasan kerja karyawan PDAM Kota Denpasar. Pengujian terhadap hipotesis ini dibuktikan dengan koefisien standardized regression weight sebesar 0,499 dan C.R sebesar 5,104 dengan Probability 0,000 atau $\mathrm{p}<0,05$, sehingga hipotesis mi nyata dapat diterima.

Hipotesis 2. Bahwa perencanaan karir individual berpengaruh signifikan terhadap kepuasan kerja karyawan PDAM Kota Denpasar. Pengujian terhadap hipotesis ini dibuktikan dengan koefisien standardized regression weight sebesar 0,285 dan C.R sebesar 3,092 dengan Probability sebesar 0,002 atau $\mathrm{p}<0,05$, sehingga hipotesis ini nyata dapat diterima.

Hipotesis 3. Bahwa perencanaan karir organisasional mempengaruhi kinerja karyawan PDAM Kota Denpasar. Pengujian terhadap hipotesis ini dibuktikan dengan koefisien standardized regression weight sebesar 0.238 dan C.R sebesar 2,065 dengan Probability sebesar 0,039 atau $\mathrm{p}<0,05$, sehingga hipotesis ini nyata dapat diterima.

Hipotesis 4. Bahwa perencanaan karir individual mempengaruhi kinerja karyawan PDAM Kota Denpasar. Pengujian terhadap hipotesis ini dibuktikan dengan nilai koefisien standardized regression weight sebesar 0,244 dan C.R sebesar 2,375 dengan Probability sebesar 0,018 atau $p<0,05$, sehingga hipotesis ini nyata dapat diterima.

Hipotesis 5. Bahwa kepuasan kerja mempengaruhi kinerja karyawan PDAM Kota Denpasar. Pengujian terhadap hipotesis ini dibuktikan dengan nilai koefisien standardized regression weight sebesar 0,231 dan C.R sebesar 2,149 dengan Probability sebesar 0,032 atau $\mathrm{p}<0,05$, sehingga hipotesis ini nyata dapat diterima.

Hasil analisis data secara statistik membuktikan bahwa terdapat pengaruh langsung positif antara perencanaan karir organisasional terhadap kepuasan kerja 
yang ditunjukkan pada nilai standaridized direct effect sebesar 0,499. ini berarti bahwa semakin baik perencanaan karir yang diadakan pihak manajemen, maka semakin puas pula karyawan PDAM Kota Denpasar dalam mencapai karir yang mereka rencanakan, dan sebaliknya, semakin buruk perencanaan karir yang diadakan oleh pihak manajemen, maka semakin karyawan tidak puas untuk mengejar karir mereka.

Hasil penelitian ini didukung oleh pendapat Tohardi (2002), yang menyatakan bahwa agar karyawan dapat meluncur mulus dalam karirnya, maka karyawan yang bersangkutan harus berusaha keras mengelola diri, bukan hanya pasrah kepada nasib. Oleh karena itu karyawan harus merencanakan karir mereka dari awal. Dengan adanya perencanaan karir yang baik dari pihak perusahaan, akan berimbas pada baiknya program pengembangan karir karyawan.

Hasil penelitian ini sejalan dengan hasil penelitian yang dilakukan oleh Trianaputri (2009) dengan judul "Pengaruh Perencanaan Karir Terhadap Kepuasan Kerja Karyawan Pada PT. Integrated Facility Service (IPS)". Hasil ini menunjukkan bahwa tanggapan responden sebagian besar adalah setuju dengan adanya perencanaan karir yang di jalankan perusahaan yang berarti bahwa terdapat pengaruh perencanaan karir terhadap kepuasan ken a karyawan pada PT. Integrated Facility Servise (IFS). Kemudian dalam jurnal Barnet \& Bradley (2007) menunjukkan bahwa dukungan organisasi, pengembangan karir kepribadian yang proaktif dan manajemen karir secara positif berpengaruh terhadap kepuasan karir karyawan. Selain itu Lavalle (2006) dalam jurnalnya yang berjudul : Career Awarness, Career Planning, and Career Transition Needs Among Sport Coaches. Hasil penelitian ini adalah mereka melakukan perencanaan karir tetapi dalam skala yang kecil. mereka juga mengakui transisi karir yang mereka perlukan. Hubungan positif juga ditemukan dalam hubungan ini yaitu perlunya sistem pendukung bagi pelatih dan kepedulian karir, perencanaan karir dan transisi karir.

Pengaruh Perencanaan Karir Individual
Terhadap Kepuasan Kerja Karyawan. Variabel perencanaan karir individual dibentuk oleh sebelas indikator. yaitu : pentingnya pengetahuan yang dimiliki, pentingnya memperbaiki diri. pentingnya pendidikan karir, pendidikan karir oleh perusahaan, pendidikan karir yang diikuti oleh karyawan, sasaran karir , kemampuan karyawan, jalur karir yang berlaku, jalur karir yang ingin dicapai, usaha-usaha pengembangan diri. dan pelatihan kerja. Indikator-indikator tersebut adalah usaha-usaha dari individu masingmasing karyawan untuk mencapai karir yang mereka inginkan.

Hasil analisis data secara statistik membuktikan bahwa terdapat pengaruh langsung positif variabel perencanaan karir individual terhadap kepuasan kerja karyawan, hal ini ditunjukkan pada nilai standaridized direct effect sebesar 0.285. ini berarti semakin baik perencanaan karir yang dilakukan karyawan. semakin mereka puas untuk mendapatkan karir yang mereka inginkan atau rencanakan. sebaliknya bila karyawan tidak merencanakan karir mereka dengan baik. mereka tidak akan merasa puas untuk mendapatkan apa yang mereka inginkan.

Hasil penelitian ini juga sejalan dengan pendapat Mathis \& Jackson (2006). yang mengemukakan bahwa perencanaan karir individual adalah perecanaan karir yang memfokuskan pada usaha-usaha individu karyawan untuk mencapai sasaran karir yang diinginkannya. Dengan adanya perencanaan karir yang dilakukan oleh masing-masing individu karyawan, maka akan terdapat usahausaha dari karyawan tersebut untuk termotivasi untuk membenahi diri agar mereka dapat mencapai sasaran karir yang diinginkannya. sehingga nantinya mereka akan merasa puas terhadap pekerjaan yang dilakukan agar dapat mencapai sasaran karir yang mereka inginkan dimasa yang akan datang.

Hasil penelitian ini sesuai dengan jurnal yang dibuat oleh Lavalle (2006) yang berjudul Career Awarness, Career Planning, and Career transition Among Sport Coaches. Hasil penelitian ini adalah mereka melakukan perenncanaan tetapi dalam skala yang kecil, 
mereka juga mengakui transisi karir yang mereka perlukan. Hubungan positif juga ditemukan dalam hubungan ini yaitu perlunya system pendukung bagi pelatih dan kepedulian karir, perencanaan karir dan transisi karir.

Pengaruh Perencanaan Karir Organisasional Terhadap Kinerja Karyawan. Hasil analisis data secara statistik membuktikan bahwa terdapat pergaulan positif dan signifikan antara variabel perencanaan karir organisasional terhadap kinerja karyawan PDAM Kota Denpasar, hal ini ditunjukkan pada nilai standaridized direct effect sebesar 0,238, standardized indirect effect sebesar 0,116 , dan total effect sebesar 0,354. Hasil analisis menunjukkan terdapat pengaruh perencanaan karir organisasional baik secara langsung maupun tidak langsung terhadap kinerja karyawan. Pengaruh dalam bentuk tidak langsung dapat dikatakan sebagai pengaruh perencanaan karir organisasional terhadap kinerja karyawan melalui kepuasan kerja.

Hasil penelitian ini sejalan dengan penelitian Kurniawan (2007), dengan judul Pengaruh Perencanaan Karir Organisasional dan Individual Terhadap Pengembangan Karir dan Kinerja Karyawan Condrad Bali Resort \& Spa, Tanjung Benoa - Badung. Hasil Penelitian ini menunjukkan bahwa perencanaan karir organisasional dan individual juga berpengaruh langsung dan tidak langsung melalui pengembangan karir, secara positif dan signifikan terhadap kinerja karyawan.

Tohardi (2002), berpendapat bahwa dengan adanya perencanaan karir yang baik, akan mampu menumbuhkan semangat dan juga sebagai motivator bagi karyawan untuk membenahi diri menjadi orang yang berprestasi sehingga akan berimbas pada kinerja yang tinggi pula. Dapat dikatakan bahwa dengan perencanaan karir yang baik dari pihak perusahaan akan berimbas pada meningkatnya kinerja yang mampu ditunjukkan oleh karyawan. Berarti dapat dikatakan bahwa penelitian ini sejalan dengan teori yang digunakan sebagai acuan.

Pengaruh Perencanaan Karir individual Terhadap Kinerja Karyawan. Hasil analisis data secara statistik membuktikan bahwa terdapat pengaruh positif dan signifikan antara variabel perencanaan karir individual terhadap kinerja karyawan PDAM Kota Denpasar. hal ini ditunjukkan pada nilai standaridized direct effect sebesar 0,244, standardized indirect effect sebesar 0.066, dan total effect sebesar 0.310. Hasil analisis menunjukkan terdapat pengaruh perencanaan karir individual baik secara langsung maupun tidak langsung terhadap kinerja karyawan. Pengaruh dalam bentuk tidak langsung dapat dikatakan sebagai pengaruh perencanaan karir individual terhadap kinerja karyawan melalui kepuasan kerja.

Secara individual, karyawan harus merencanakan karirnya sendiri, karena dengan merencanakan karir sendiri, karyawan akan terus melakukan usaha-usaha pengembangan diri. Usaha-usaha pengembangan diri yang dapat dilakukan karyawan antara lain, berprestasi di bidang yang dikerjakannya, melakukan pendekatan dengan pihak-pihak yang terkait dengan pengembangan karir, dan mengikuti pendidikan dan pelatihan yang diadakan oleh perusahaan. Dengan prestasi kerja yang tinggi, para karyawan beranggapan bahwa prestasi kerja tersebut akan membantunya mengembangkan karir, sesuai dengan rencana karir yang diinginkan karyawan tersebut. Adanya perencanaan karir dari individu karyawan akan membuat karyawan semakin memotivasi untuk berprestasi sehingga karyawan merasa puas terhadap pekerjaan yang telah dilakukannya sehingga nantinya akan membuat karyawan tersebut memiliki kinerja yang tinggi.

Hasil ini sejalan dengan penelitian yang dilakukan oleh Dewi (2009) dengan hasil penelitian menunjukkan bahwa perencanaan organisasional dan individual berpengaruh terhadap kinerja karyawan PDAM kabupaten Badung. Sinergi antara perencanaan karir organisasional dan perencanaan karir individual, akan menciptakan suatu pengembangan karir yang baik. yang akan menjadi motivasi bagi karyawan untuk berkinerja tinggi sehingga tujuan organisasi dapat tercapai. 
Pengaruh Kepuasan Kerja Terhadap Kinerja Karyawan. Variabel kepuasan kerja dibentuk oleh sebelas indikator, yaitu : kesempatan naik jabatan, hubungan antar karyawan, kecukupan gaji, kenaikan gaji berkala, peraturan dan prosedur perusahaan, atasan yang kompeten, kesesuaian tugas dan fungsi, kenyamanan ruang kerja, pengakuan atas hasil kerja, komunikasi, dan kecukupan tunjangan. Kesebelas indikator tersebut terbukti membentuk variabel kepuasan kerja.

Variabel kinerja karyawan dibentuk oleh sepuluh indikator, yaitu, ketepatan waktu menyelesaikan pekerjaan, disiplin dalam melaksanakan tugas, kemauan belajar, teliti daiam melaksanakan tugas, kejujuran atau integrasi, tanggungjawab pada tugas, jiwa kepemimpinan, kerjasama, kemampuan menyelesaikan laporan. kesepuluh indikator tersebut terbukti membentuk variabel kinerja karyawan.

Hasil analisis data secara statistik membuktikan bahwa terdapat pengaruh langsung positif variabel kepuasan kerja terhadap kinerja karyawan, hal ini ditunjukkan pada nilai standardized direct effect sebesar 0.231. ini berarti semakin baik kepuasan kerja dari karyawan, maka semakin baik pula kinerja karyawan PDAM Kota Denpasar, sebaliknya semakin buruk kepuasan kerja karyawan. semakin buruk pula kinerja karyawan.

Kinerja karyawan salah satunya dipengaruhi oleh kepuasan kerja karyawan. Ketidakpuasan kerja muncul ketika harapan seseorang tidak terpenuhi. Banyak faktor yang dapat mempengaruhi kepuasan kerja seorang karyawan. yaitu : pekerjaan itu sendiri, gaji/ upah. pengakuan. hubungan antara pimpinan dan bawahan, dan kesempatan untuk maju (Mathis \& Jackson, 2006). Pendapat ini juga di dukung oleh hasil penelitian sebelumnya yang menyatakan bahwa kepuasan kerja berpengaruh terhadap kinerja karyawan. Pendapat ini disampaikan dalam Thesis Kuraesin (2008), Dianingrum (2006), Pugno \& Depedri (2009) dan McCue P \& Gianakis (1997)bahwatingkatkepuasan paraprofesional merupakan fungsi dari korespondensi antara pengharapan, aspirasi, kebutuhan dan tingkat sejauh mana organisasi memenuhi kebutuhan dan menyesuaikan pengharapan dan aspirasi. Profesionalisme dipenuhi dengan pengakuan yang mereka terima dari orang lain, keuntungan yang berkaitan dengan pekerjaan mereka dan arahan serta saran yang mereka terima. Kepuasan kerja karyawan akan berimplikasi pada kegairahan kerja yang pada akhirnya berdampak pada kinerja karyawan.

\section{SIMPULAN DAN SARAN}

Perencanaan karir organisasional berpengaruh positif dan signifikan terhadap kepuasan kerja karyawan PDAM Kota Denpasar, yang berarti semakin baik perencanaan karir yang dilakukan oleh organisasi, maka karyawan PDAM Kota Denpasar semakin puas dalam pekerjaannya, sebaliknya semakin buruk perencanaan karir yang dilakukan oleh organisasi, semakin karyawan tidak terpuaskan dalam pekerjaannya.

Perencanaan karir individual berpengaruh positif dan signifikan terhadap kepuasan kerja karyawan PDAM Kota Denpasar, yang berarti semakin baik karyawan PDAM Kota Denpasar dalam merencanakan karirnya, maka semakin terpuaskan karyawan dalam pekerjaannya, sebaliknya semakin buruk karyawan PDAM Kota Denpasar dalam merencanakan karirnya, semakin rendah kepuasan kerjanya.

Perencanaan karir organisasional berpengaruh positif dan signifikan terhadap kinerja karyawan PDAM Kota Denpasar, yang berarti semakin baik perencanaan karir yang dilakukan oleh organisasi, maka semakin baik kinerja karyawan PDAM Kota Denpasar, sebaliknya semakin buruk perencanaan karir yang dilakukan oleh organisasi, semakin buruk pula kinerjanya.

Perencanaan karir individual berpengaruh positif dan signifikan terhadap kinerja karyawan PDAM Kota Denpasar, yang berarti bahwa semakin baik karyawan merencanakan karirnya, maka semakin baik pula kinerja karyawan PDAM Kota Denpasar, sebaliknya semakin buruk karyawan merencanakan karirnya, semakin buruk pula 
kinerjanya.

Kepuasan kerja berpengaruh positif dan signifikan terhadap kinerja karyawan PDAM Kota Denpasar, yang berarti semakin baik kepuasan kerja karyawan, maka semakin baik kinerja karyawan PDAM Kota Denpasar, sebaliknya semakin rendah kepuasan kerja karyawan. semakin rendah pula kinerjanya.

\section{REFRENSI}

Barnet, R., \& Bradley, L. (2007). The Impact of Organization Support for Career Development on Career Statisfaction. Economis Journal. United State.

Dewi, N. K. D. K.(2009). Pengaruh Kecerdasan Emosional, Norma Subjektif dan Kontrol Perilaku Pada Minat Berkarir Mahasiswa Pendidikan Profesi Akuntansi Menjadi Akuntan Publik.

Dianingrum, M. (2006). Pengaruh Pengembangan Karir, Pengawasan. Kepemimpinan, Kepuasan Kerja dan Komitmen Organisasi Terhadap Kinerja Karyawan Di Kantor Terminal Peti Kemas Gedebage. Tesis. Program Magister Manajemen Universitas Jenderal Soedirman.

Ferdinand, A. (2002). Structural Equation Modelling dalam Penelitian Manajemen, Aplikasi Model-model Rumit dalam Penelitian untuk Tesis Magister dan Disertasi Doktor. Semarang: Universitas Diponegoro.

Ghozali, I., \& Chairi. (2007). Teori Akuntansi. Semarang: Badan Penerbit Universitas Diponegoro.

Handoko, T. H. (2001). Manajemen Personalia dan Sumberdaya Manusia. Yogyakarta: BPFE Press.

Kuraesin, H. I. S. D. (2008). Pengaruh Motivasi dan Kepuasan Kerja Terhadap Kinerja Karyawan PT. Pos Indonesia (Persero) Cabang Bandung 40000 (Survey Pada
Karyawan PT. Pos Indonesia Persero Cabang Bandung 40000). Tesis. Bandung: Universitas Pendidikan Indonesia.

Kurniawan, I. (2007). Pengaruh Perencanaan Karir Organisasional dan Individual Terhadap Pengembangan Karir dan Kinerja Karyawan Conrad Bali Resort \& Spa, Tanjung Benoa Badung. Tesis. Denpasar : Universitas Udayana.

Lavalle, D. (2006). Career Awarness, Career Planing, and Career Transition Needs Among Sport Coaches. Economis Journal.

Luthans, \& Frens. (2006). Perilaku Organisasi (10th ed.). Yogyakarta: Andi.

Mangkunegara, A. A., \& Prabu, A. (2006). Evaluasi Kinerja SDM. Bandung: PT. Refika Aditama.

Martoyo, S. (2000). Manajemen Sumber Daya Manusia. (4th ed.). Yogyakarta: BPFE.

Mathis, R. L., \& Jackson, J. H. (2006). Manajemen Sumberdaya Manusia. Jakarta: Salemba Empat.

McCue P, C., \& Gianakis, G. A. (1997). The Relationship Between Job Satisfaction and Performance The Case of Local Goverment Finance Officer in Ohio. Economis Journal. United State.

Pugno, M., \& Depedri, S. (2009). Job Performance and Job Satisfaction: an Integrated Survey. United State. Economis Journal.

Riduwan. (2008). Metode dan Teknik Menyusun Tesis. Bandung: Alfabeta.

Rivai, V. (2005). Manajemen Sumber Daya Manusia Untuk Perusahaan dan Teori ke Praktek. (1st ed.). Jakarta: PT. Raja 
Gravindo Persada.

Simamora, H. (2004). Manajemen Sumberdaya Manusia. Yogyakarta: Sekolah Tinggi Ilmu Ekonomi YPKN.

Sugiyono. (2017). Metodologi Penelitian Kuantitatif, Kualitatif, dan R\&D. Bandung: CV Alfabeta.

Tika, H. M. P. (2006). Budaya Organisasi dan Peningkatan Kinerja Perusahaan. Jakarta: PT. Bumi Aksara.
Tohardi, A. (2002). Pemahaman Praktis Manajemen Sumberdaya Manusia. Bandung: Penerbit Mandar Maju.

Trianaputri., N. (2009). Pengaruh Perencanaan Karir Terhadap Kepuasan Kerja Karyawan Pada PT. Integrated Facility Service (ISS). Tesis. Program Magister Manajemen Universitas Brawijaya, Malang. 